\title{
Introduction: Stories of Science and Empire
}

This day relenting God

Hath placed within my hand

A wondrous thing; and God

Be praised. At his command, Seeking his secret deeds

With tears and toiling breath, I find thy cunning seeds, O million-murdering Death. I know this little thing A myriad men will save, O Death, where is thy sting? Thy victory, $\mathrm{O}$ Grave?

—Ronald Ross, 'Reply’ in Philosophies (1911)

Britain's first Nobel Prize belongs to parasitology. In India, in 1897, a Scottish pathologist named Ronald Ross (Fig. 1) identified a protozoan parasite called Plasmodium in the stomach of a mosquito. It was a Eureka moment. ${ }^{1}$ This was a vital step in confirming that malaria was transmitted via the bite of an insect vector, the Anopheles mosquito. He rushed to his desk and drew out three slips of paper: the first to make diagrams of what

${ }^{1}$ In his autobiography, Ross writes that 'when I awoke with my mind refreshed my first thought was: Eureka! The problem is solved!' Ronald Ross, Memoirs, with a Full Account of the Great Malaria Problem and Its Solution (London: John Murray, 1923) p. 224.

(C) The Author(s) 2022

E. Taylor-Pirie, Empire Under the Microscope, Palgrave Studies in

Literature, Science and Medicine, https://doi.org/10.1007/978-3-030-84717-3_1 
Fig. 1 Sir Ronald Ross with his microscope. (Wellcome Collection. Attribution 4.0 International $(\mathrm{CC}$ by 4.0$)$ )

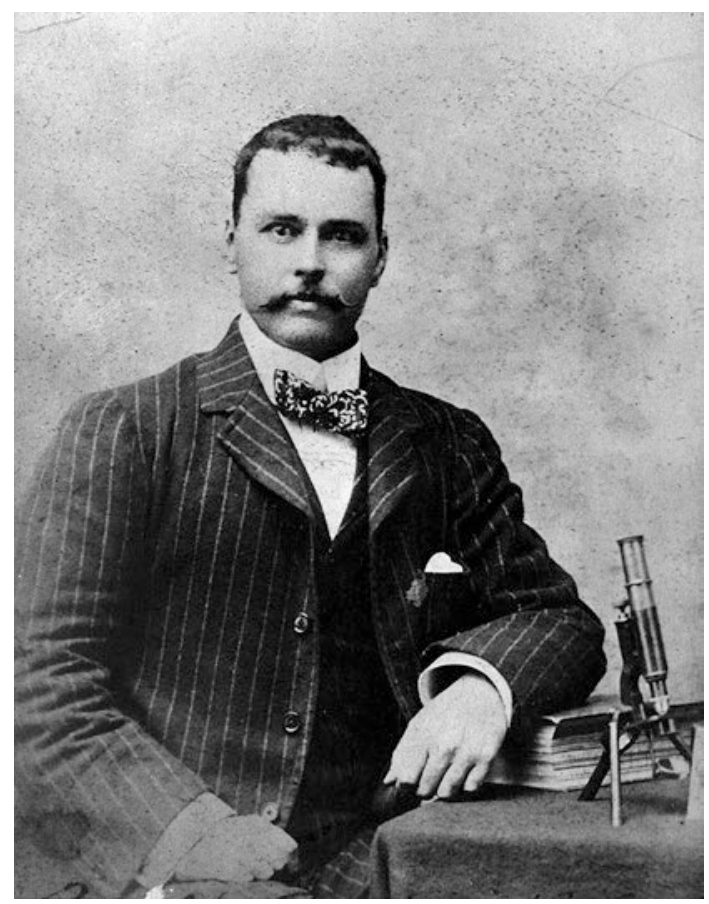

he saw, the second to write to his wife with the news, and the third to pen a poem that would define the moment for years to come. As he dissected the mosquito, he also 'cut the Panama Canal'. ${ }^{2}$ This was the moment that Ross conquered 'million-murdering death' and 'la[id] one of the stones upon which w[ould] rest the everlasting bastions of a strong and vigorous Empire'. ${ }^{3}$ Or so the story goes. This book is about the story of parasitology. It is about science and empire, and the stories we tell ourselves about science and empire. In the following pages, I explore how the material and imaginative architecture of imperialism produced tropical medicine, which, in turn, reimagined empire in its own image.

2 'Death of Sir Ronald Ross. Life of Research into Tropical Diseases', Tamworth Herald, Saturday 24 September 1932, p. 3.

${ }^{3}$ London, London School of Hygiene and Tropical Medicine (Hereafter: LSHTM). Ross Collection (Hereafter: RC) GB 0809 Ross/131/01/20. 'Empire Leading Article-Imperial Bacteriology', The Financial News, 23 January 1913. 
As Gordon C. Cook claims in his 2007 study Tropical Medicine: An Illustrated History of the Pioneers, '[T]ropical medicine was [...] an integral part of Joseph Chamberlain's plan for "constructive imperialism"'. It would therefore be 'accurate', he argues, 'to envisage colonial politics as exploiting a newly established discipline for its own ends'. ${ }^{4}$ Michael Worboys upholds a similar opinion in his essay on the emergence of tropical medicine, recounting the ways in which research about tropical diseases directly facilitated colonial expansion. ${ }^{5}$ John Farley goes as far as to claim that tropical medicine was so imperial in its concerns, discourses, and implementation that rather than a medical specialty, it became 'a branch of political imperialism' ${ }^{6}$ This process was reciprocal: many historians including Worboys point out that father of tropical medicine, Patrick Manson, also exploited Chamberlain's imperial vision to further his own ideas about the discipline, suggesting that while tropical medicine provided a legitimising narrative for British colonial dominance, Britain's imperial project, at the same time, provided political authority for this emerging specialty.

Contemporary British parasitologist Frank Cox has explored how the question of what parasitology is has shaped the history of the discipline. Given that the parasitic lifestyle is common to helminths, bacteria, viruses, protozoa, fungi, parasitoid insects, some plants like mistletoe, and even birds like cuckoos, there is - and has historically been-a need to narrow down the subject of study. Cox uses the understanding of 'discipline' as a 'social institution' to trace the emergence of parasitology to the second half of the nineteenth century and specifically to the publication of the field's first dedicated journal Parasitology in 1908. This social understanding of 'discipline' makes the formation of institutions, societies, and specialist journals (enabling like-minded individuals to meet and exchange ideas) a watershed moment. As Cox notes, the aim of the new journal of Parasitology was to encourage the publication of papers 'relating to pathogenic and disease-transmitting parasites with particular reference to

\footnotetext{
${ }^{4}$ Gordon C. Cook, Tropical Medicine: An Illustrated History of the Pioneers (London: Academic Press, 2007) p. 34.

${ }^{5}$ Michael Worboys, 'The Emergence of Tropical Medicine: A Study in the Establishment of a Scientific Specialism' in Perspectives on the Emergence of Scientific Disciplines ed. by Gerard Lemaine, Roy McLeod, Michael Mulkay, and Peter Weingart (Chicago: Aldine Publishing, 1976) pp. 75-98.

${ }^{6}$ John Farley, Bilharzia: A History of Imperial Tropical Medicine (Cambridge: Cambridge University Press, 1991) p. 293.
} 
protozoa, entozoa and arthropods'. ${ }^{7}$ As he asserts elsewhere, since parasitic diseases (by this definition) 'occur mainly in the tropics, the field of parasitology tended to overlap with that of tropical medicine'. ${ }^{8}$ Medical historians Michael Worboys and Helen J. Power have similarly argued that the histories of parasitology, vector biology, and tropical medicine are entwined, whilst John Farley recognises tropical medicine as the 'main impetus for the emergence of parasitology as a discipline in Britain'.?

I locate my study in this watershed moment at the cusp of the emergence of parasitology as a social discipline, and one focused on the parasitehost, and later parasite-host-vector relationship in colonial settings. Thus, for the purposes of this book, I use the terms parasitology and tropical medicine to refer broadly to the same discourse, which was often characterised and thus might be thought of as the 'science of empire'. Parasitology was not, however, simply the sum of its sciences. It was also shaped by stylistic, formal, and material exchanges with the humanities. Empire Under the Microscope navigates convergences and interdependencies between the fields of 'literature and science' and 'history of science' to illuminate and scrutinise the imaginative work that underpins the twin constructs of empire and empiricism in this period.

As a member of the Indian Medical Service, Ross championed the intertwinement of scientific research and the British imperial project. $\mathrm{He}$ published widely in the medical and lay presses, held a prominent position as a professor at the Liverpool School of Tropical Medicine, and gave a $\mathrm{BBC}$ radio lecture on malaria-broadcast to over a million-in 1924 . He held a post as consultant on malaria to the War Office and later consultant on tropical diseases to the Ministry of Pensions. He was regularly heralded as a 'benefactor of the race' by journalists, considered a figurehead for the practical application of medical science, and was widely recognised for his expertise in the field of parasitology. And yet when English writer and

${ }^{7}$ F. E. G. Cox, 'George Henry Falkiner Nuttall and the Origins of Parasitology and Parasitology’ Parasitology 136 (2009) 1389-94 (p. 1392).

${ }^{8}$ F. E. G. Cox, 'History of Human Parasitology', Clinical Microbiology Reviews, 15.4 (2002), 595-612 (p. 595).

${ }^{9}$ See: Helen J. Power, 'History of Parasitology' eLS (25 April 2001) https://doi. org/10.1038/npg.els.0003074; Michael Worboys, 'Emergence and Early Development of Parasitology' in Parasitology ed. by K. S. Warren and J. Z. Bowers (New York: Springer, 1983 ) pp. 1-18; John Farley, 'Parasites and the Germ Theory of Disease' in Framing Disease: Studies in Cultural History ed. by Charles E. Rosenberg and Janet Golden (New Brunswick: Rutgers University Press, 1992), p. 43. 
critic Rodolphe Louis Mégroz described Ross's career in 1930, it was in the following words: 'after heroic and solitary labours, [he] earned undying fame as a medical scientist, [but he] had begun as a poet and remained essentially a poet'. ${ }^{10}$ These unconventional credentials reflect not only Ross's attempts to sustain a career as an amateur poet and novelist (cultivating friendships with now canonical writers like Arthur Conan Doyle, H. Rider Haggard, and poet laureate John Masefield), but also his own conscious framing of his medical career in terms of not just scientific but also poetic inspiration.

For many, Ross's Nobel discovery was first accessed through his poem, 'Reply' (quoted at the beginning), which was republished in medical presses such as the Indian Medical Gazette, The Lancet, and the British Medical Journal; in national, regional, and colonial newspapers; in popular science books; and in biographies and obituaries. ${ }^{11}$ The poem was even memorialised on a gate of commemoration near Ross's old laboratory in Calcutta, erected by the governor of Bengal in 1927 (Fig. 2).

For the Yorkshive Post, Ross's poem 'crystallis[ed] the spirit [of his work]', which

ha[d] saved not a million, but millions of men, made habitable a vast area of the earth's surface and made possible, it is scarcely an exaggeration to say, the continued existence of the British Empire. ${ }^{12}$

Ross continued to write and publish poems inspired by his sanitary work and his political views, especially regarding educational policy, the nature of scientific discovery, and the relationship between science and the state.

\footnotetext{
${ }^{10}$ R. L. Mégroz, 'Sir Ronald Ross as Fiction Writer' The Bookman 79.469 (October 1930) $14-16$ (p. 14).

${ }^{11}$ See for example: 'Ronald Ross' Birmingham Daily Post, Monday 20 August 1917, p. 4; 'Malaria Secret in Verse' Sunderland Daily Echo and Shipping Gazette, Wednesday 13 May 1931, p. 9; 'Saviour of a Million' Hartlepool Northern Daily Mail, Wednesday 13 May 1931, p. 4; 'Conqueror of Malaria' Dundee Evening Telegraph, Wednesday 13 May 1931, p. 6; 'Saved a Million Lives' Gloucester Citizen, Wednesday 13 May 1931, p. 12; 'Saviour of a Million Lives' Lancashire Evening Post, Wednesday 13 May 1931, p. 4; 'Sir R. Ross's Birthday' Aberdeen Journal, Thursday 14 May 1931, p. 6; 'Celebrated in Poetry' Gloucester Journal, Saturday 16 May 1931, p. 16; 'Sir Ronald Ross Dead' Dundee Courier, Saturday 17 September 1932, p. 5; 'Sir Ronald Ross' Western Morning News, Saturday 17 September 1932, p. 7; 'Mosquito Day and the Man Who Conquered Malaria' Yorkshire Evening Post, Saturday 17 August 1940, p. 4.

12 'Ronald Ross' Yorkshire Post Saturday, 17 September 1932, p. 10.
} 


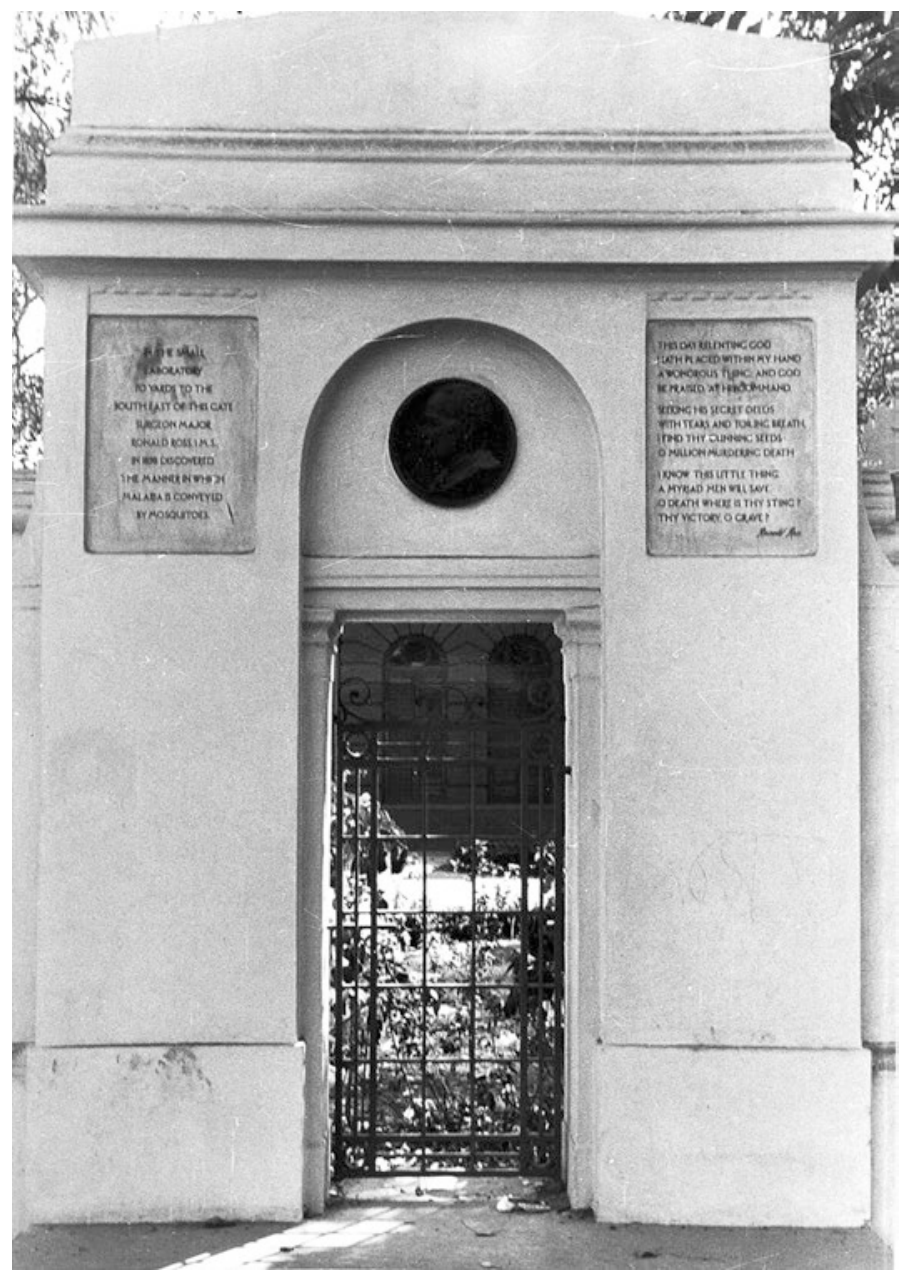

Fig. 2 Ross Memorial Gate in Calcutta. (Wellcome Collection. Attribution 4.0 International (CC by 4.0)) 
By the 1930s, even the prime minister, Ramsay MacDonald, had read Ross's poetry. Speaking to a reporter in 1932, he remarked, 'I have often confounded my scientific friends by taking from my bookshelves books of verse and showing them Ross's name on the title page'. ${ }^{13}$ In 1911, Ross had published an anthology of his poetry in tandem with a textbook on malaria, perceiving the two works as complementary. Thus, the understanding of his discovery was constituted, in Ross's own hand, by the practices of both science and art. In the preface to his poetic anthology, he urges us to view the poems (which were written in India during his malaria researches between 1881 and 1899) as 'not a diary in verse, but rather the figure of a work and of a philosophy', suggesting that they do more than simply record his labours. ${ }^{14}$

For others, Ross's discovery was laid out definitively in his Memoirs, written in 1923, and the many biographies, histories, and journalistic opeds for which it became a resource. Indeed, it was hugely influential, shaping histories of malaria, mediating priority disputes with Italian researchers, and informing the Royal Society's obituary of Ross, along with many and varied newspaper columns and, later, eulogies. In Memoirs-a genrebending text that includes microscope drawings and clinical observations alongside his poetry, personal recollections, and letter correspondenceRoss promises to 'reconstruct the events [of his discovery] as exactly as [he] can out of [his] notebooks, letters, and memories'. Immediately following this promise, we are treated to a glimpse of the poetic subjectivity with which he understood his own research as he sets the scene for us: 'the sky was filled with a haze of dust through which the sun glared like a foiled enchanter' (217). This is followed by a characteristic diversion into verse before lapsing back into the taxonomy of mosquitoes. Throughout he draws on Ancient Greek myth and Romantic iconography to reconstitute his scientific discovery as a heroic feat of endurance culminating in a poetic denouement.

Empire Under the Microscope thus contends that the story of parasitology is incomplete without considering the significant encounters and exchanges that the field had with the literary and historical imagination. It considers the significance of the years 1885-1935, a 50-year period that takes the institutionalisation of parasitology in the Liverpool and London

13 'Sir Ronald Ross. Death of Pioneer in War Against Malaria', The Scotsman, Saturday 17 September 1932, p. 13.

${ }^{14}$ Ronald Ross, Philosophies (London: John Murray, 1911) p. iv. 
Schools of Tropical Medicine (1898 and 1899) as its mid-point. This is also a period that maps almost directly onto what Cox has identified as the 'golden age' of parasitology (1875-1925), and a period dominated by the bellicose jingoism of the New imperialism. ${ }^{15}$ Not only did research in parasitology filter through to inform literary and cultural understandings of empire, but literary-linguistic practices themselves became intrinsic to the production and reception of parasitological knowledge. In public and private communications, parasitologists reformulated the imperial contexts of their discipline by conceptualising their research using British myths of nationhood. By reaching back to the real and imagined past, they could manipulate the narrative power of British political and geographical dominance, whilst also distancing themselves from the more unsavoury aspects of contemporary imperial administration.

Invoking literary archetypes such as the Arthurian knight and envisaging their research within a quest narrative, they capitalised on the popularity and flexibility of the adventure mode to construct an association between scientific progress and national prowess that is often taken for granted. In addition to this role in popularisation and self-fashioning, forms and modes borrowed from literature became scaffolding with which parasitologists structured their own understandings of the discipline and their place within society. Likewise, parasitic diseases like trypanosomiasis (African sleeping sickness) and malaria were manipulated by novelists and journalists to imaginatively map the British Empire in relation to existing geopolitical ideologies about space and race. Using Ross and his colleagues as access points to a wider professional culture, I explore (and interrogate) literary and scientific forms of knowledge about tropical medicine, uncovering cross-fertilisations that had a lasting impact on our attitudes to scientists, on our conceptions of disease, and on our understandings of empire.

At the turn of the nineteenth into the twentieth century, parasites and parasitic diseases became protagonists in scientific narratives, plot devices in fiction, objects and subjects of government and educational policy, and poster children for the value of British imperialism. They provided a lens through which writers might scrutinise British global citizenship, a citizenship that was underscored by conversations about Britain and its global power structures. It is the shifting meanings of parasites and parasitic

${ }^{15}$ F. E. G. Cox, 'The Golden Age of Parasitology-1875-1935: The Scottish Contributions' Parasitology 144 (2017) 1567-81. 
disease as they move across genres, modes, and audiences that most interest me. How do they operate as models for thinking about society, self, and nation? How are the 'heroic' narratives of turn-of-the-century parasitology reasserted in grand historical narratives of Western scientific progress? How do parasitology's geopolitical stakes map onto fiction about the British imperial project?

\section{SCIEnCeHumanities}

In 2016, James Castell, Keir Waddington, and Martin Willis developed the term ScienceHumanities as a blended version of the more traditional literature and science binary that 'positions the disparate disciplines of the sciences and humanities in close proximity'. As they note:

$[\mathrm{T}]$ he elision of the space between "science" and "humanities" is emblematic of the transdisciplinary nature of the ScienceHumanities; which works across and between the disciplines and their methodologies, seeking to find new knowledge in the interstices of their joining together rather than in their separate spheres. ${ }^{16}$

In this book, I attempt to navigate this elided space, recognising that science-like the humanities - is culturally embedded and thus responds to, produces, and enacts the 'social' and 'cultural' in its own practices.

As N. Katharine Hayles argues, knowledge is encoded 'not merely into words but also into practices, institutions, and material conditions'. ${ }^{17}$ Therefore, Empire Under the Microscope examines the linguistic, social, and material networks that informed parasitology as a fledgling discipline immersed within, and thus formed by, an imperialist culture that supported particular understandings of the world. I am interested in the stories that emerge at the intersections of these networks. What happens when circulating ideas about parasitic disease move through and are interpreted by disparate organising principles like the methodologies of empiricism or the formal techniques of the novel? Or more specifically, what happens when parasitologists draw on literary forms to engage more

${ }^{16}$ James Castell, Keir Waddington, and Martin Willis, 'ScienceHumanities: Introduction' Journal of Literature and Science 10.2 (2017) 1-5 (p. 1).

${ }^{17}$ N. Katharine Hayles, 'Introduction: Complex Dynamics in Literature and Science' in Chaos and Order: Complex Dynamics in Literature and Science ed. by N. Katharine Hayles (Chicago: University of Chicago Press, 1991) p. 4. 
meaningfully with the public? When readers of the Indian Medical Gazette are directed to an imperial romance novel for the aetiology of sleeping sickness? Or when journalists insist upon a likeness between tropical pathology research and the detective work of Sherlock Holmes?

Martin Willis has illuminated the ways in which medicine throughout the Victorian period was underpinned by a 'richness of connections between literary culture and institutionalized science', and much scholarly work has explored the multi-vocal intellectual landscape of the long nineteenth century in the context of a transition from a 'predisciplinary' to a more formally disciplinary culture. ${ }^{18}$ In her foundational work, Gillian Beer drew attention to the 'shared discourse' of this period in which 'not only ideas, but metaphors, myths, and narrative patterns could move freely and rapidly to and fro between scientists and non-scientists'. ${ }^{19}$ The idea, as she contends elsewhere, that individuals 'work with the metaphors and thought-sets historically active in their communities' partly explains why, for example, parasitologists found themselves employing the concept of King Arthur and his knights to conceptualise their work-after all, the publication of Alfred Tennyson's Idylls of the King (1859-1885) and the first modernisation of Malory's compilation of Arthur's tales had given Arthurian fantasy new cultural currency, as I explore in my first chapter. ${ }^{20}$

From Beer's field-defining work Darwin's Plots (1983), to George Levine's Darwin and the Novelists (1988), to Devin Griffith's The Age of Analogy (2016), scholars have been interested in not only the shaping function of language but also of form, and have found ample material in evolutionary theory. For Levine, nineteenth-century science and the

\footnotetext{
${ }^{18}$ Martin Willis, 'Scientific Cultures and Institutions' in The Routledge Research Companion to Nineteenth Century British Literature and Science ed. by John Holmes and Sharon Ruston (Abingdon: Routledge, 2017) pp. 30-40 (p. 30). This is somewhat of a false dichotomy, given that medical and scientific specialisms do, of course, predate the nineteenth century, and as Gowan Dawson notes, the Royal Society's insistence on 'self-consciously plain and non-figurative language' in scientific communications in the late seventeenth century suggests a much earlier fragmentation of the 'one culture' model. However, the nineteenth century does provide fertile ground for exploring the imagined nature of disciplinarity at a time when many writers and practitioners were concerned with demarcating professional identity. See: Gowan Dawson, 'Literature and Science Under the Microscope' Journal of Victorian Culture 11.2 (2006) 301-15 (p. 311).

${ }^{19}$ Gillian Beer, Darwin's Plots: Evolutionary Narrative in Darwin, George Eliot, and Nineteenth-Century Fiction, 3rd Edn (Cambridge: Cambridge University Press, 2009) p. 5.

${ }^{20}$ Gillian Beer, Open Fields: Science in Cultural Encounter (Oxford: Oxford University Press, 1996) p. 8.
} 
nineteenth-century novel are 'cultural twins' that share common assumptions and ideals. ${ }^{21} \mathrm{He}$ contends that 'science enters most Victorian fiction not so much in the shape of ideas, as quite literally, in the shape of its shape, its form, as well as in the patterns it exploits and develops, the relationships it allows'. ${ }^{22}$ Griffiths too focuses on the 'shape' of science, arguing that both novelistic interventions and evolutionary theory used analogy to facilitate encounters with the past. These twinned enterprises (of imagining historical worlds and of imagining inaccessibly theoretical ones) rested on the power of analogy to 'establish a pattern of similarity between two different sets of relationships'. ${ }^{23}$

What Griffiths calls the 'comparative turn' of the nineteenth century was galvanised by the emergence of the historical novel as a mode that enabled a new historical sensibility to flourish. This historical sensibility is evident in textbooks regarding the prevention of malaria wherein parasitologists compared contemporary knowledge and intervention to that of historical empires, particularly Ancient Greece and Rome. In this way, comparative historicism contextualised parasitology research in relation to imperial practices through time. Political proponents also invoked this model; at a banquet held in honour of the London School of Tropical Medicine, Alfred Lyttelton, Secretary of State for the Colonies, toasted 'the Empire' and reportedly 'contrasted its gigantic dimensions with those of the Roman empire'. ${ }^{24}$ Indeed, parasitology as a branch of knowledge was deeply intertwined with historical commentary. From medical textbooks to newspaper columns, writers provided timelines of thought and discovery stretching back to Biblical times to preface current work in the field. Tropical medicine was often narrated in terms of discoveries madea practice that demonstrated international collaboration, even as it was weaponised to legitimise individual priority claims.

When William Osler, Regius Professor of Medicine at Oxford, set up the History of Medicine section (later society) at the Royal Society of Medicine in 1912, Ross was a founding supporter. He was personally invited to join by Osler and served as vice-president, alongside Regius Professor of Physic (medicine) at Cambridge Thomas Clifford Allbutt;

${ }^{21}$ George Levine, Darwin and the Novelists: Patterns of Science in Victorian Fiction (Cambridge: Harvard University Press, 1988) p. vii.

${ }^{22}$ Levine, p. 13.

${ }^{23}$ Devin Griffiths, The Age of Analogy: Science and Literature Between the Darwins (Baltimore: Johns Hopkins University Press, 2016) p. 28.

24 'London School' Aberdeen Journal and Press, Thursday 11 May 1905, p. 6. 
two previous presidents of the Royal Society of Medicine (Henry Morris and William Selby Church); and Dr Richard Caton, former Lord Mayor of Liverpool and vice-chair of the Liverpool School of Tropical Medicine. ${ }^{25}$ Tropical medicine was thus well represented on the committee. Ross's interests in the importance of history to contextualise science can also be seen in his editorship of Science Progress (1913-1932) in which he frequently published histories of medical and scientific specialities, as well as essays advocating the teaching of the history of science. ${ }^{26}$ This is also an arena in which he laid out his ideas for a melded approach to science and art. As he argued in an article about the proposed opening of a national Shakespeare theatre, 'the real educators are not the schoolmasters but the poets, the men of science, and the historians'. ${ }^{27}$ In a review of John Masefield's Sonnets and Poems published in a 1917 issue, he insisted:

Science and poetry are twin sisters whose office is to seek and to sum. Twice blessed is he who is inspired by both; for the man of science should be a poet, and the poet a man of science-not prepensely perhaps, but in caste. The one sister gives the flame without which seeking is seldom successful; and the other such reality as will keep the mind from losing itself in the clouds. Thus the goddesses walk ever hand in hand-pure spirits lifting the mind of man, or, indeed, making it. ${ }^{28}$

In the same issue, he published Masefield's poem 'The Choice', which, he remarked, would be of interest to 'scientific minds'. In Masefield's poetry, Ross argued, we hear the 'pure harmony' of 'the voices of both the divine sisters singing together $[\ldots]$ it is a quest of the Holy Grail of Beauty by the Sir Perceval of poets' (444).

This last sentence demonstrates the kind of rhetorical encounters that I explore in my first chapter, where I trace the influence of the Greek muses and of Arthurian legend on projects of professional self-fashioning at the

25 'Royal Society of Medicine. Section of the History of Medicine' The Lancet 180.4657 (30 November 1912) 1504-09.

${ }^{26}$ Whilst Science Progress courted a predominantly scientific and professional readership, it was regularly reviewed in the literary supplement of The Times, the Yorkshire Post, the Aberdeen Journal, the Oxford Chronicle, and Nature, among other journals.

${ }^{27}$ Ronald Ross, 'A Shakespeare Theatre' Science Progress, 16.62 (October 1921) p. 285.

${ }^{28}$ Ronald Ross, 'THE SISTER OF SCIENCE by Ronald Ross on Sonnets and Poems by John Masefield' Science Progress, 11.43 (January 1917) 441-44. Masefield was himself interested in science and wrote a novel about sleeping sickness in 1909 called Multitude and Solitude, as discussed in later chapters. 
turn of the century. Gawain and Galahad joined Perceval in the imaginations of parasitologists as they adapted historical and poetic models of chivalry to reconceptualise the relationship between medicine and empire. As I argue, parasitologists reached back to the real and imagined past to promote their research specialty as a source of national pride and so make the case for professional recognition and support. Capitalising on the narrative power of British myths of nationhood and the cultural currency of Greco-Roman mythology, parasitologists framed themselves as modern 'knights of science' fighting on behalf of imperial Britain. Individual researchers were lionised as national heroes and their research framed as labour that would command the longevity of legendary stories like those recounted in Homeric poems or medieval romance.

The success of these stories of science is reflected in the many newspaper articles, opinion pieces, and biographies that were written in the 50 years following Ross's discovery. In 1910, a writer for British political weekly newspaper The Nation insisted that Ross's poetic retelling of his discovery would become 'part of our national heritage [...] to the man of science no song of triumph could be nobler'. ${ }^{29}$ Meanwhile Sir Edward Russell, editor of the Liverpool Daily Post and Mercury, reinforced the rhetoric of the 'knights of science' by remarking: 'it is as though Hector himself, in the pauses of the fight, had sung the siege of Troy'. ${ }^{30}$ English writer Osbert Sitwell wrote a preface to Mégroz's biography of Ross in 1931 in which he insisted that Ross's dual nature as scientist and poet should be 'a cause of pride and pleasure to all Englishmen'. Who can fail to feel a 'stir of patriotism' when reading of Ross's achievements he asks'it is the achievements of such men more than football matches and battles that move those who love their country'. ${ }^{31}$ For writers like Sitwell parasitology inspired the same a kind of patriotism as team sports and military victories.

When I employ the term parasitology, I do so to refer to a set of ideas and practices associated with the aetiology and control of human tropical parasitic disease, coextensive with projects of professional self-fashioning. As I demonstrate throughout, parasitologists employed literary and

${ }^{29}$ [No Title] The Nation, 15 October 1910, quoted in Ronald Ross, Philosophies (London: John Murray, 1911).

${ }^{30}$ Edward Russell, [No Title], Liverpool Daily Post and Mercury, 3 October 1910, quoted in Ross, Philosophies.

${ }^{31}$ R. L. Mégroz, Ronald Ross: Discoverer and Creator (London: George Allen and Unwin, 1931) p. 9. 
historical forms of knowledge when conceptualising themselves and their subfield. In doing so, they often inscribed a form of white, Anglophone exceptionalism into the stories of parasitology and empire, using historical and literary 'imagined communities' to bolster their claims to the public purse and stabilise the authority of their profession. The legacy of this remains with us and continues to augment the relationships between science, society, and the state. I am indebted to Bruno Latour's ActorNetwork theory, which considers the critical role of not just people but also places, objects, and texts in the development and practice of science, and to Benedict Anderson's concept of imagined communities, which offers a model for conceptualising how disparate individuals might imagine themselves as part of a community larger than themselves (e.g. a nation) through the circulation and consumption of printed media. Nationhood and nationalism, Anderson argues, are cultural artefacts that command 'profound emotional legitimacy' through individuals' subscription to 'imagined political communities'. ${ }^{32} \mathrm{He}$ identifies the novel and the newspaper, in particular, as 'two forms that provided the technical means for representing the kind of imagined community that is the nation' (25).

I consider how parasitology participated in the formation and consumption of such 'imagined communities' by analysing how tropical medical knowledge was articulated in articles and correspondence in the medical press (including the British Medical Journal, the Lancet, and the Indian Medical Gazette); in medical lectures and speeches; in travel writing such as Henry Morton Stanley's In Darkest Africa (1890) and Edward Glave's In Savage Africa (1892); in medical travelogues such as Arthur Torrance's Tracking Down the Enemies of Man (1928); in medical biography such as Ross's own Memoirs, as well as biographies of Ross by Rodolphe Louis Mégroz, John Rowland, and James Oram Dobson; and in popular medical histories such as Ronald Campbell Macfie's The Romance of Medicine (1907) and Paul de Kruif's Microbe Hunters (1926). Across this diverse range of texts-with disparate and overlapping readerships - writers mapped the contours of empire with reference to parasitic disease, triangulating a kind of imperial nationhood that valorised British geopolitical dominance through medicine and upheld a Carlylean 'great man' narrative of history.

\footnotetext{
${ }^{32}$ Benedict Anderson, Imagined Communities: Reflections on the Origin and Spread of Nationalism (London: Verso, 2006) p. 4.
} 
Quoting from A. E. Grant's Indian Manual of Hygiene (1894), Mark Harrison identifies how medical writers employed militarised language in Indian sanitary literature to frame sanitary officers as heroic figures: 'to win the doubting and careless ones to his side and to enlist them under the banner of hygiene; to fight continually and untiringly against all foes to the health of mankind'. ${ }^{33}$ Harrison's own characterisation of these references as 'Kiplingesque' points to another entanglement that I explore throughout this book - that of the relationship between medicine and imperial romance. ${ }^{34}$ In my second chapter, I consider how parasitology became rhetorically and materially entangled in the imperial imagination with travelogues, anthropological treatise, imperial romance fiction, and missionary biography. These modes jointly constructed the colonial encounter as a feat of manly endurance, using the linguistic enjoinment of medicine and exploration to frame parasitologists as modern heroes. Examining the influence of Thomas Carlyle's conceptualisation of the heroic in history, I demonstrate how tropical illness became a subject rhetorically associated with pioneers, poets and prophets, mapped onto the larger field of empire by the adventure mode.

Whilst in my first chapter I consider the temporal framing of parasitology, here I examine how parasitologists thought about their discipline in spatial terms. In Ross's Memoirs, he compares his discovery of the malaria parasite inside the salivary glands of the mosquito in 1898 to 'a geological prospector discover[ing] gold, or diamonds, or oil, somewhere in India' (314), a comment that demonstrates the shared geographical and medical vision of empire. By using analogies such as gold prospecting and geographical exploration, parasitologists signalled the political value of their discoveries by emphasising the similarity of their methodologies to geographers, cartographers, and commercial miners. Indeed, their work, which often involved accompanying explorers on expeditions, collecting specimens, and creating sanitary maps, facilitated slippages of profession that were highlighted through language and form. Mapping was a particularly flexible mode, which parasitologists manipulated to locate their research in relation to global politics-from the use of cartographic language in

\footnotetext{
${ }^{33}$ Mark Harrison, 'Towards a Sanitary Utopia? Professional Visions and Public Health in India, 1880-1914' South Asia Research 10.1 (1990) 19-40 (p. 21).

${ }^{34}$ I use imperial romance here as a placeholder for imperial adventure fiction more generally as well as to refer to imperialist fantasies that romanticised the colonial encounter.
} 
medical lectures to the incorporation of mapping techniques in medical textbooks that sought to delimit tropical and temperate diseases.

A series of gold and diamond rushes in California, Australia, South America, and South Africa from the 1850s onwards provided a new motivation for colonial exploration, reframing the colonies in the popular imagination as spaces of endless bounty. ${ }^{35}$ In 1883, the Athenaeum reported that the 'closer knowledge' of West Africa acquired since the second Ashanti war (1873-1874) had 'revealed that the soil of the whole of the British protectorate is impregnated with gold, and that it may be also expected to supply copper, zinc, iron, and precious stones'. ${ }^{36}$ Accordingly, treasure-seeking was increasingly incorporated into narratives of triumphant exploration. In imperial adventure stories-from Robert Louis Stevenson's Treasure Island (1883) to Jules Verne's The Southern Star (1884) to H. Rider Haggard's King Solomon's Mines (1885) - it quickly became a preferred plot device because, as explorer Richard Burton wrote in 1883, 'geography is good but gold is better'. ${ }^{37}$ The trope also infiltrated the medical imagination; parasitologists drew on it as a way of contextualising their research in relation to geographical discovery and themselves in relation to pioneering explorers-or even the fictional adventurers of imperial romance. By analysing the bodies of patients, already established to parallel allegorically the colonial landscape, parasitologists-like explorers - might find 'treasures that for ages have been missed', wrote one reviewer in the Annals of Tropical Medicine and

\footnotetext{
${ }^{35}$ Helen Goodman notes: 'The "Star of Africa" diamond was found in Griequaland West in 1869, and in 1871 many more of the gems were found where the Orange and Vaal Rivers meet, leading to the British annexation of the Transvaal. Wilkie Collins's The Moonstone (1868) had popularised the literary plot of the search for a diamond from colonial India, and Haggard's King Solomon's Mines combined mystery with heroic adventure, blending military nostalgia with the topical subject matter of real-life treasure hunts'. Goodman, "“A Story of Treasure, War, and Wild Adventure": Hero-Worship, Imperial Masculinities, and InterGenerational Ideologies in H. Rider Haggard's 1880s Fiction' in Martial Masculinities: Experiencing and Imagining the Military in the Long Nineteenth Century ed. by Michael Brown, Anna Maria Barry, and Joanna Begiato (Manchester: Manchester University Press, 2019) pp. 232-54 (p. 241).

36 'To the Gold Coast for Gold. By Richard F. Burton and Verney Lovett Cameron. 2 vols. Maps and Illustrations (Chatto and Windus)' The Athenaeum 2880 (6 January 1883) 11-12 (p. 11).

${ }^{37}$ Richard F. Burton, 'Preface' in To the Gold Coast for Gold, a Personal Narrative by Richard F. Burton and Verney Lovett Cameron, Vol I (London: Chatto and Windus, 1883) p. x.
} 
Parasitology in $1910 .^{38}$ Ross makes similar comments in his Memoirs, recalling that he searched the bodies of mosquitoes for malaria parasites 'with the same passion and care as one would search some vast ruined palace for a little hidden treasure' (224). In his letters to Manson (written in the 1890s), he says that he feels like "Aladdin in the cave of the "lamp"I can't carry away all I can lay my hands on' (261), and upon his eventual success, he asserts: 'the door is unlocked, and I am walking in and collecting the treasures' (301).

In 1897, a reviewer for Sydney Thayer's Lectures on Malaria (1897) similarly invoked the concept of gold prospecting, but this time to critique medical knowledge about malaria:

The biography of the malarial fevers has by now assumed enormous proportions, for although many important veins remain to be followed up, the malarial mine has already been very thoroughly worked. In the process, much pure metal has been extracted. A great deal of valuable material is still mixed, however, with baser mineral, and unfortunately the literature also is encumbered with quantities of spurious ore... ${ }^{39}$

By using the image of a 'malarial mine', the writer implies a correspondence between the intellectual and material resources of the tropics, making the prevention of malaria synonymous with the notion of 'striking gold'. This dynamic not only critiques the currency of the wealth of intellectual material about malaria but also reminds us that research in parasitology, like the mining of geological resources, was an activity that supported imperial power. Ross makes this political connection even more explicit in his Memoirs when he criticises the lack of government response to his malaria work by comparing it to the response that would undoubtedly have followed if he had indeed discovered gold, or-placing malaria in the position of an imperial enemy - if, let us say, a hill tribe had committed some depredation'. Then, he argues, 'the authorities would have brought up an army against them at a cost of a million rupees' (314).

The euphemistic use of 'treasure' in medical writing finds a parallel in a subset of imperial romance stories where tropical illness and its cure began to displace other subjects as the focus of plot. In such stories, treasure and

38 'Annals of Tropical Medicine and Parasitology by The Liverpool School of Tropical Medicine' British Medical Journal 2.2595 (1910) p. 880.

${ }^{39}$ L. F. B. 'Notes on New Books' John Hopkins Hospital Bulletin 8.81 (December 1897) 265-67 (p. 266). 
medical progress become synonymous - as in Henry Seton Merriman's With Edged Tools (1894) in which the characters seek a secret African drug called 'Simiacine', which grows at a plateau in the forests and promises to be a lucrative, cure-all. John Masefield's Multitude and Solitude (1909) and Joseph Hocking's The Dust of Life (1915) offer similar plots: in the first, the characters travel to Africa with the intention of finding an experimental cure for sleeping sickness, and in the second, the British protagonist, Cedric, catches sleeping sickness and is saved by a native African who knows of a cure hidden in the African interior. This cure becomes Cedric's passport into high society, securing him riches and winning him a wife. By switching out treasures for cures, these imperial romance novels play out a medicalised version of rediscovering the Garden of Eden. As Charlotte Rogers has explored, European writing about the tropics had long been composed with reference to biblical place-myths. When Christopher Columbus discovered the South American continent (a result of his selfreported obsession with finding 'gold'), he announced that he had discovered a terrestrial paradise. ${ }^{40}$ Ross uses Columbus as a guiding metaphor for scientific discovery and its disruptions, writing 'for the second time I was to be interrupted just as I had the conclusion of the human malaria work within easy reach [...] Columbus having sighted America was ordered off to discover the North Pole!' (318). When his experiments proved successful, he exclaimed that he had 'found the Treasure Island $[. .$.$] the Promised$ Land' (239). As I explore in my first chapter, the concept of the 'promised land' was also invoked in acclimatisation debates to conceptualise resourcerich Africa. Such analogies were not only communicative strategies but also informed the practical methodologies of the discipline by positioning microscopic analysis as akin to imperial cartography and geographical exploration.

As a primary methodological tool the microscope came to emblematise the field's concern with hidden worlds. The challenges inherent in conceptualising the microscopic produced a vocabulary that emphasised the superior visual capabilities of the parasitologist, which found a popular parallel in the techniques of the police detective. In my third chapter, I trace the cultural encounters between the parasitologist and the scientific detective in the medico-popular imagination, revealing how such meetings positioned parasites as the 'invisible assassins' of empire, and helped

\footnotetext{
${ }^{40}$ Charlotte Rogers, Jungle Fever: Exploring Madness and Medicine in Twentieth-Century Tropical Narratives (Nashville: Vanderbilt University Press, 2012) p. 6.
} 
to embed the figure of the doctor-detective in public understandings of science. ${ }^{41}$ Scottish doctor and poet Ronald Campbell Macfie (1867-1931) followed a popular tradition by referring to the parasites of malaria and sleeping sickness as 'murderers' and 'criminals' with 'chequered and adventurous career[s]' in his 1907 book The Romance of Medicine. ${ }^{42}$ Likewise journalists routinely invoked Sherlock Holmes as a frame of reference when reporting on research in tropical medicine.

Consequently, parasitologists were associated with a cultural fantasy about the scientific method that was itself informed by the 'romance' of medicine embodied by assertions like Macfie's that 'the history of science is the history of a few great men fighting single-handed to establish truth' (5). I examine Sherlock Holmes and kindred archetypes of the scientific detective in the context of tropical medicine to reflect on cross-pollinations that helped to consolidate the imagined power and authority of science as a tool of legal, moral, and social control. Holmes continues to have cultural currency in clinical and diagnostic medicine, as numerous articles in medical journals attest. Here, and at the fin de siècle, he operates, not just as an aspirational model for the objectivity of science, but as a complex and contradictory shorthand that reflects the messiness of the scientific method even as it attempts to stabilise the authority of science. By placing the formal strategies of detective fiction in dialogue with the representational strategies of parasitology, I disentangle some of the threads that continue to underpin our fraught cultural understandings of the scientific method, explicating the joint imaginative work and shared vocabularies of literature and medicine.

Whilst some authors-like Arthur Conan Doyle, H. Rider Haggard, and, to a lesser extent, John Masefield - had first-hand experience of parasitic disease drawn from their time spent in the colonies, for other writers, their knowledge of tropical disease was begotten in more indirect ways and based on assumptions that had become naturalised. This 'unread' knowledge, this second-, third-, fourth-hand science is often the knowledge that asserts itself most forcefully. As George Levine notes, despite its apparent upending of anthropocentric hierarchies, evolutionary theory was widely engaged with in part because it told a compelling and alreadyextant narrative. It, Levine contends, 'found ostensibly scientific form for

${ }^{41}$ Paul de Kruif, Microbe Hunters (New York: Harcourt, Brace, and Company, 1926) p. 137.

${ }^{42}$ Ronald Campbell Macfie, The Romance of Medicine (London: Cassell and Co., 1907) pp. 144-46. 
the ideologies that dominated Victorian society'. ${ }^{43}$ This is much the stance I take for parasitologists, whose theories and practices appeared to offer a 'scientific form' for imperial and national ideologies. In my fourth chapter, I examine how one particular tropical disease, sleeping sickness, was conceptualised as a form of tropical violence across a range of medical and nonmedical genres. I reveal how Henry Seton Merriman's sensational literary depiction of sleeping sickness in With Edged Tools (1894) made its way into newspaper reports and clinical case studies, augmenting debates about racial susceptibility. For writers like Merriman, tropical disease provided a rhetorically flexible scaffold for mapping the moral and emotional fault lines of empire. By collapsing several aetiological modes into one multivalent metaphor of atmospheric 'irritability', With Edged Tools reveals how geopolitical anxieties about imperial administration were embedded into conceptualisations of health and disease.

In Unfinished Empire, John Darwin argues that 'more or less organised violence played a huge part in British expansion'. He draws attention to War Office paperwork in 1902 that, in compiling a list of the principal British wars between 1857 and 1899 settled on 15-a not insubstantial number, despite leaving out many lesser conflicts including those in Kenya, Uganda, Nigeria, and the Eastern Cape of South Africa. ${ }^{44}$ In my final chapter, I analyse the enduring and mobile metaphor of medicine as war to illuminate how imperial military forms encoded violence into narratives of parasitology and vector biology in ways that legitimised equally violent political interventions. The broad analogy of medicine as warfare enabled readers and listeners to gain access to a new conceptual domain-the microbiological.

Scholars such as Lorenzo Servitje, Michael Brown, Anne Marie Moulin, and Roger Cooter have explored the historical and rhetorical intertwinement of medicine and war. ${ }^{45}$ The 'war and epidemics couplet' (Cooter)

${ }^{43}$ Levine, Darwin and the Novelists, p. 3.

${ }^{44}$ John Darwin, Unfinished Empire: The Global Expansion of Britain (London: Penguin Books, 2012) pp. 117-18.

${ }^{45}$ Lorenzo Servitje, Medicine Is War: The Martial Metaphor in Victorian Literature and Culture (Albany: SUNY Press, 2021); Michael Brown, 'Like a Devoted Army: Medicine, Heroic Masculinity, and the Military Paradigm in Victorian Britain' Journal of British Studies, 49.3 (2010) 592-622; Anne Marie Moulin, 'The Defended Body' in Medicine in the Twentieth Century ed. by Roger Cooter and John Pickstone (London: Routledge, 2003), pp. 385-98; Roger Cooter, 'Of War and Epidemics: Unnatural Couplings, Problematic Conceptions' Social History of Medicine 16.2 (2003) 283-302. See also: Paul Hodgkin, 
and the broader 'figurative construction of medicine as war' (Servitje) owe their dominance, in part, to the contexts of the development of microbiological knowledge, much of which was produced in or around military medical establishments, and which 'gave enormous ground to the metaphor of "war on disease" both in medicine and society'. ${ }^{46}$ Moreover, the biopolitical interventions of public health naturalised practical and theoretical entanglements between warfare and medical practice. Mark Harrison has referred to these entanglements as the medicalisation of the military and the militarisation of medicine, asserting that as a 'mode of discipline' medicine 'contributed to the emergence of modern forms of military organisation' and was 'valued as an administrative and managerial resource'. ${ }^{47}$ Many parasitologists, especially before the establishment of schools of tropical medicine, worked in the Colonial Medical Services (e.g. Ross, George Giles, Leonard Rogers, David Douglas Cunningham, and Charles Donovan), or the Royal Army Medical Corps (e.g. David Bruce and William Leishman). Ross was also consultant in malariology to the British War Office in 1917, and so it is perhaps unsurprising that military language was one of the forms that he reached for when discussing malaria.

By close reading texts such as H. G. Wells's The War of the Worlds (1898) and Bram Stoker's Dracula (1897), alongside Manson and Ross's

'Medicine is War: and Other Medical Metaphors' British Medical Journal (Clinical Respiratory Education) 291.6511 (21 December 1985) 1820-21; Scott L. Montgomery, 'Codes and Combat in Biomedical Discourse', Science as Culture 2.3 (1991) 341-90; David Cantor, 'The Diseased Body' in Medicine in the Twentieth Century ed. by Roger Cooter and John Pickstone (London: Routledge, 2003), pp. 347-66 (especially, p. 349); Laura Otis, Membranes: Metaphors of Invasion in Nineteenth-century Literature, Science, and Politics (Baltimore: Johns Hopkins University Press, 1999); Roger Cooter, Mark Harrison, and Steve Sturdy (eds), War, Medicine and Modernity (Stroud: Sutton Publishing, 1998); Roger Cooter, Mark Harrison, and Steve Sturdy (eds), Medicine and Modern Warfare (Amsterdam: Rodopi, 1999); Mark Harrison, Public Health in British India: Anglo-Indian Preventive Medicine (Cambridge: Cambridge University Press, 1994) and 'Medicine and Management of Modern Warfare' History of Science 34.4 (1 December 1996) 379-410; David Arnold, Colonizing the Body: State Medicine and Epidemic Disease in Nineteenth Century India (Berkeley: University of California Press, 1993). For more general scholarship on how conceptual metaphors are organising principles for our understanding and experience of the world, see: George Lakoff and Mark Johnson, Metaphors We Live By (Chicago: Chicago University Press, 1980).

${ }^{46}$ Cooter, 'Of War and Epidemics', p. 293.

${ }^{47}$ Mark Harrison, 'The Medicalization of War-The Militarization of Medicine' Social History of Medicine 9.2 (1 August 1996) 267-76. 
characterisations of parasite-vector-host relationships, I examine how the microbiological imagination made its mark on anxious imperial fictions in which ontological uncertainty and declining confidence in the longevity of British geopolitical dominance were aggregated. Dracula's 'blood and soil' motif, for example, plays on the doubleness of blood as a symbol of heredity and as a medium for disease, and soil as a symbol of homeland and as a culture medium for parasites. Implicit in both figurations is a conceptual and rhetorical confluence between British and microbial 'colonies'- a dyad that embodies related anxieties about cultural and biological reverse-colonisation, as explored by critics like Stephen Arata and Laura Otis. By excavating the medical and political contexts of popular cultural forms like the vampire, this chapter historicises lexes of contagion and parasitism that persist in contemporary political discourse surrounding immigration.

Throughout this book, I invoke several established models from the field of literature and science in order to chart a course through what is a very messy landscape. When I talk of exchanges and encounters, Gillian Beer's 'two-way traffic', the 'shape' of science, the 'form' of the novel, it is with the caveat that what is happening here is not neat, linear, or easy to distinguish. The models rarely map the reality faithfully because the reality is plural, overlapping, mobile, and contradictory. When we speak of literature and science, it is tempting to assume two well-defined monoliths with equal and opposite directions of flow. Much more helpful is the image of multiple, loosely defined hubs of sciences and literatures engaging in unequal amounts of active and passive exchanges and assimilations. To coopt Darwin's oft-borrowed metaphor, we might contemplate the relationship between these forms of knowledge as like an entangled bank-with 'empire' and 'parasitology' as 'the plants that grow, the birds the sing, the insects that flit, and the worms that crawl' within this complex ecosystem, and literature and science as part of a subsoil of ideas, metaphors, and narrative patterns that are sometimes difficult to disentangle but which provide rich nutrients and support fruitful encounters. ${ }^{48}$ At the intersections

${ }^{48}$ Darwin closes his On the Origin of Species with the now-famous metaphor: 'It is interesting to contemplate an entangled bank, clothed with many plants of many kinds, with birds singing on the bushes, with various insects flitting about, and with worms crawling through 
of plot and form, we find new ways of understanding the world that do not always respect boundaries of genre, as when novelistic encounters with disease are referenced in medical magazines, when literary reviewers of novels praise the novelist's role as a communicator of science, or when Ross eulogises his colleagues' contributions to the science of empire using literary archetypes from the Knights of the Round Table.

\section{Medicine, Gender, And Nation}

Empire Under the Microscope is explicitly about race, gender, and nationhood, and-because the writers and readerships I examine are predominantly middle class - it is also implicitly about class. It is about the power of language and the authority of science, the stories we tell ourselves and the images we find meaning in. A significant proportion of the book is concerned with professional self-fashioning. Heather Ellis has outlined the symbiotic evolution of the 'man of science' and professional discourses of masculinity throughout the nineteenth century. Changing ideas about gender and science in this period created the potential for new models of scientific masculinity; two such models were the 'scientific poet' and 'scientific hero', both of which come to form part of Ross's professional identity in the late century.

Ellis describes efforts to rehabilitate the reputation of the man of science with the establishment of the British Association for the Advancement of Science (BAAS) in 1831. She argues that the BAAS drew much of its aesthetic direction from poet-scientist Humphrey Davy, who longed to realise Francis Bacon's vision of a 'masculine' science. Although historians of science have often engaged with the idea of the masculine authority of science in this period, Ellis argues that they tend to present it as an enduringly stable phenomenon. Challenges to this authority are the exception rather than the rule. This, she contends, is not reflective of reality. Davy and his contemporary Alexander von Humboldt, for example, were seen not only as models of masculine virility but also as 'dandies' by some of their peers. Proponents of the BAAS continually fought against persistent

damp earth, and reflect that these elaborately constructed forms, so different from each other, and dependent on each other so complex a manner, have all been produced by laws acting round us'. Charles Darwin, On the Origin of Species by Means of Natural Selection, or the Preservation of Favoured Races in the Struggle for Life (1859; London: The Folio Society, 2006) p. 388. 
notions of the scientist as reclusive and effeminate or self-indulgent and foppish. ${ }^{49}$ Like Ellis, I focus on the important role that self-fashioning played in attempting to stabilise the authority of science and follow Jan Golinski's direction by investigating how the identity of the scientist was 'formed from a variety of cultural resources, including those used to shape masculine identity in society at large'. ${ }^{50}$ These resources include depictions of the 'warrior ideal', 'chivalric knight', and 'soldier hero', models which scholars such as Michael Paris, Mark Girouard, and Graham Dawson have explored in relation to imperial masculinity. ${ }^{51}$

Given that my focus is predominantly on a mode of self-fashioning that privileged a masculine ethos of self-sacrificing heroism, it is perhaps unsurprising that the texts I examine are mostly composed by male writers and about male researchers. This is not to say that there weren't female writers, researchers, or travellers-perhaps most famously, Mary Kingsley (1862-1900) explored Africa as an anthropologist, ethnographer, entomologist, and outspoken social reformer. In her Travels in West Africa (1897) she speaks of tropical disease at length. Indeed, in 1903, the Liverpool School of Tropical Medicine instituted a medal in her name, which was awarded to many of the parasitologists and administrators that I discuss, including Patrick Manson, Robert Koch, Alphonse Laveran, Joseph Chamberlain, William MacGregor, George Nuttall, Malcolm Watson, and David Bruce.

Parasitologist David Bruce, who was touted as the 'Sherlock Holmes of science', had a major scientific collaborator in his wife, microbiologist Mary Elizabeth Bruce (née Steele) (1849-1931), with whom he published more than 30 technical papers (Fig. 3). As his obituary noted:

They were never apart, she accompanied him during all his foreign service, and worked daily with him at home and abroad, in the laboratory, in the hospital and in the field, taking part in all his investigations. Bruce always

\footnotetext{
${ }^{49}$ See Heather Ellis, Masculinity and Science in Britain, 1831-1918 (London: Palgrave Macmillan, 2017) p. 125.

${ }^{50}$ Jan Golinski, Making Natural Knowledge: Constructivism and the History of Science, with a New Preface (Chicago: Chicago University Press, 2008) p. xiii.

${ }^{51}$ See Michael Paris, Warrior Nation: Images of War in British Popular Culture, 1850-2000 (London: Reaktion Books, 2000); Mark Girouard, The Return to Camelot: Chivalry and the English Gentleman (New Haven: Yale University Press, 1981); Graham Dawson, Soldier Heroes: British Adventure, Empire and the Imagining of Masculinities (Abingdon: Routledge, 1994).
} 
Fig. 3 Parasitologists Lady Mary and Sir David Bruce. (Reproduced with permission from Royal Society of Tropical Medicine and Hygiene)

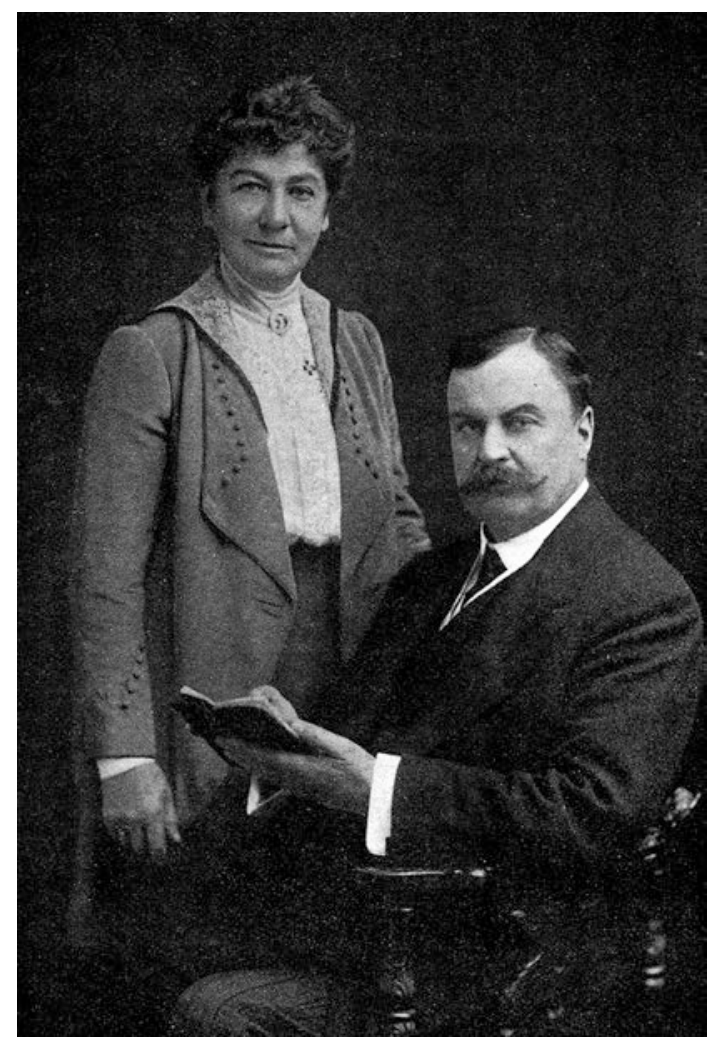

laid stress on the great services his wife rendered him and when he lay on his death-bed he very definitely expressed the wish that any notice of his scientific work that might be made should include a statement of how much he had been indebted to her in the prosecution of all his work. She excelled in all laboratory technique as well as in drawing and she had taken care to learn methods in Koch's laboratory in Berlin, where she and her husband worked for some time during a leave period on return from Malta in $1888 .^{52}$

Newspaper coverage highlighted Mary Bruce's scientific expertise in discussions of her husband, insisting that she was his constant companion

${ }^{52}$ J.R.B, 'Sir David Bruce (1855-1931)' Obituary Notices of the Fellows of the Royal Society 1.1 (1 December 1932) 79-85 (p. 80). 
and that 'he was always anxious to pay tribute to the assistance and encouragement he received from his wife' ${ }^{53}$ As records show, she was not merely 'encouraging', but rather a collaborator with considerable technical skill'it was with her invaluable assistance on the microscopic side that he discovered the causative organism [of Malta fever]'. ${ }^{44}$ She was awarded an O.B.E. for her work on the aetiology and control of trench fever and tetanus during the First World War.

Another member 'of the small band of pioneer women scientists in a not-too-appreciative masculine world' is parasitologist Muriel Robertson (1883-1973), who carried out important research on trypanosomes in Ceylon. ${ }^{55}$ She later joined the Lister Institute of Preventative Medicine as a member of staff and was appointed protozoologist to the Protectorate of Uganda in 1911. She did extensive work in the field of veterinary parasitology, as a lengthy obituary in the Biographical Memoirs of the Fellows of the Royal Society attests, as well as work on gas gangrene for which she was sought after for advice by Royal Army Medical Corps bacteriologists. She was awarded a Doctorate of Science from Glasgow University in 1922. Two of her sisters also qualified in medicine, one taking up general practice in Limavady, Northern Ireland.

Mary Bruce, Mary Kingsley, and Muriel Robertson were all praised for their femininity - the first described as 'all that is associated with the word womanly', the second as 'a womanly woman in every sense of the word', and the third as 'thoroughly feminine'. ${ }^{56}$ This complicates the idea of scientific authority as the sole preserve of the masculine realm in this period and deserves sustained and separate attention, which is, regrettably, outside the purview of this book. ${ }^{57}$ Bruce, Kingsley, and Robertson constitute just three of the many female scientists and researchers who lived and worked within the period I investigate. As the Lancashire Evening Post

53'Sir David Bruce Dies During Wife's Funeral Service' Daily Mirror, Saturday 28 November 1931, p. 6.

${ }^{54}$ Weldon Dalrymple-Champneys, 'Wives of Some Famous Doctors' Proceedings of the Royal Society of Medicine 52 (3 June 1959) 937-46 (p. 945).

${ }^{55}$ Ann Bishop and Arnold Ashley Miles, 'Muriel Robertson, 1883-1973' Biographical Memoirs of the Fellows of the Royal Society 20 (1 December 1974) 317-47 (p. 317).

${ }^{56}$ J.R.B, 'Sir David Bruce (1855-1931)', p. 81; Edmund D. Morel, Affairs in West Africa (London: William Heinemann, 1902) p. xiv; Bishop and Miles, 'Muriel Robertson, 1883-1973', p. 344.

${ }^{57} \mathrm{~A}$ study of the many women who blazed trails as tropical pathologists in the nineteenth century is overdue. 
pointed out in 1899, there were almost '200 lady doctors on the Register from the London School of Medicine for Women alone, and nearly 40 institutions - such as hospitals, lunatic asylums, \&c.- - have women doctors on their staffs' ${ }^{58}$ The writer insisted that the 'lady doctor' had justified 'her status by clever and self-sacrificing work. She has shown her fitness for the calling in which grit, determination, patience, and pluck are almost essential to success by plodding and fighting on', perpetuating the inscription of a kind of martial endurance in medical science that is more often seen as the 'natural' preserve of men. Empire Under the Microscope explores how parasitology produced narratives that encouraged a predominantly white, predominantly male understanding of medicine, which finds a legacy not only in the persistent gender disparity in STEM but also in gender biases in histories of science and medicine.

In their professional self-fashioning, parasitologists made use of modes and forms traditionally associated with masculine action: war, adventure, hunting, and sports. This was continuous with what Ellis identifies as attempts to 'rebrand' the man of science more generally from the midcentury. Examining the role of the X Club (1864-1890) - a dining club that is thought to have wielded wide influence over scientific thoughtshe explains how there was a shift away from placing emphasis on 'birth, wealth and inherited status' and towards 'individual merit, moral worth and self-discipline: from nobleness of birth to nobleness of character' ${ }^{59}$ Scientists like Thomas Henry Huxley aimed to reform science, to free it from the 'trammels of religion and politics' and instead champion a more active, democratic, and secularly moralistic type of practice.

From the BAAS to the X Club via historian Thomas Carlyle's writings on heroism and hero-worship, Ellis delineates consistent efforts to

reinvigorate the man of science in the public mind - as a figure of masculine authority connected to the real world, entrusted to the public to inform them about scientific progress and to lobby government on their behalf about the need to fund science appropriately. (8)

This ideal resonates with parasitologists' efforts to elevate their discipline in the public mind as well as their appeals to politicians and colonial administrators for funding and support. However, unlike Huxley, many

58 'Our Lady Doctors' Lancashive Evening Post, Friday 18 August 1899, p. 2.

${ }^{59}$ Ellis, p. 125. 
parasitologists combined this emphasis on action with a performative Christian sensibility and an overtly political motivation. This is reflected in Ross's poetic appeals to 'relenting God', his many subsequent biographies-which were often written and published by Christian student movements - and his insistence on the geopolitical role of parasitic diseases:

malaria is a great enemy of the explorer, the missionary, the planter, the merchant, the farmer, the soldier, the administrator, the villager and the poor $[\ldots]$ profoundly modif[ying] the world's history $[\ldots]$ It is essentially a political disease. ${ }^{60}$

Ronald Campbell Macfie similarly wrote of the 'vast political importance' of microbes in 1907. For Macfie, the two 'most important' microbesthose of tuberculosis and malaria-'not only slay individuals but build empires' ${ }^{61}$ Macfie demonstrates the racism that underpins the entanglements between tropical medicine and empire by privileging nationalist politics over global health, insisting that microorganisms are themselves 'prince[s] of Imperiali[ $\mathrm{sm}]$ ' who have 'connived at our designs [and] plotted for us' (156). He upholds a standard Western narrative of medical and imperial progress by asserting that the 'conviction of the mosquito' opened up continents to 'the conquest of the Caucasian'; however, by conceding that without epidemics Europeans would have been 'checkmated' by the 'black problem all over the world', he also reveals a microbially inflected eugenicism that invokes disease as bioweapon (155-56).

Whilst many cultural historians and literary scholars have focused on the use of disease as a marker of foreignness - as a way for Western writers to label global others as threats to national health and culture-Macfie's words demonstrate an awareness of the destruction wrought by colonialism on those othered communities. As Margaret Delacy observes 'armies carried syphilis and typhus that proved deadlier than fire and the sword; and a handful of explorers and settlers slaughtered millions of indigenous people with measles and smallpox'. ${ }^{62}$ Not much has changed; in 2010, United Nations aid workers travelling to Haiti following a devastating earthquake brought still more devastation with them in the form of

${ }^{60}$ Ronald Ross, The Prevention of Malaria (London: John Murray, 1910) p. viii.

${ }^{61}$ Macfie, The Romance of Medicine, p. 155.

${ }^{62}$ Margaret Delacy, Contagionism Catches On: Medical Ideology in Britain, 1730-1800 (London: Palgrave Macmillan, 2017) p. 3. 
cholera, which prompted an epidemic that killed thousands of Haitians (3). The global Covid-19 pandemic that rages whilst I write this introduction illustrates once again how we reach for blame narratives that assign homelands to illness. Whilst relatively little is known about the origins of SARS-CoV-2, the viral pathogen responsible for Covid-19, its first appearance in Wuhan, China, has led to a global political discourse that has demonised Chinese people, governance, hygiene, and cultural practices. From bat soup to secret laboratory experiments, speculations about the emergence of this novel coronavirus and its subsequent politicisation as 'the Chinese virus', 'Wuhan virus', and even 'kung-flu' (names reminiscent of the 'yellow peril' narratives of the late nineteenth century) have coincided with reported rises in anti-Asian hate crimes globally.

Disease does not 'belong' to any one community and yet, as this book seeks to demonstrate, the stories we tell about disease are invariably bound up with ideas about political and national identity. In her recent book Malaria and Victorian Fictions of Empire (2019), Jessica Howell argues that malaria narratives are principally narratives of 'place' and 'displacement', with medical and nonmedical writers alike re-scripting malaria, particularly during the period of the New Imperialism (1870-1914), as 'a disease of "out there" rather than "right here"'. ${ }^{63}$ Authors of fiction, she argues, use the cyclic and remittent forms of malaria to structure chronology, plot, and characterisation, whilst malaria's narrative displacement as a disease of 'out there' is borne out in the 'mapping of subjects' national characters and health in relationship to 'malarial geographies' (8). This process of othering malaria was part of a larger project of renegotiating British and imperial nationhood in the wake of a changing medical, disciplinary, and political landscape. In his 1910 book, The Prevention of Malaria, Ross rescripts malaria precisely in this way, insisting that malaria was not endemic to Ancient Greece or the Roman empire, but rather was introduced from 'without':

Mr Jones, following a tentative suggestion of mine, gives many reasons in favour of the view that [malaria] may have entered [Greece and Italy] from without during historical times, and may subsequently have exerted considerable influence upon their civilisation.

${ }^{63}$ Jessica Howell, Malaria and Victorian Fictions of Empire (Cambridge: Cambridge University Press, 2019) p. 6. 
He considers it unlikely that malaria could have been prevalent in Greece because 'the people were too vigorous and warlike'; the figures on the tombstones, 'though evidently idealised' do not suggest to his medical mind 'a malarious race' (2). He clearly sees malaria as playing a role in the history of civilisation, asserting that once it was introduced it 'sapped the vigour and physique of the race'. If malaria is a threat to civilisation, it makes political and ideological sense for Ross to map this threat as a historical import rather than an endemic problem.

Mark Harrison argues that the dominant belief in 'the distinctiveness of the tropical environment and its maladies' was part of a process of conceiving difference and hierarchy that facilitated European expansion. ${ }^{64}$ The extreme version of this narrative involved thinking in binary oppositions: tropical and temperate, salubrious and pathogenic, primitive and civilised. Such forms are, for Caroline Levine, portable organising principles that pervade fictional and nonfictional texts alike. ${ }^{65}$ Both Laura Otis and Stephen Arata have recognised the function of such binaries in constructing imperial metropolitan identity. Self and other-perhaps the ultimate binary-are categories that do ideological work in fictional texts. In different ways, Otis and Arata identify how the translocation of foreign 'others' to British space in novels articulates an anxiety about the integrity of British racial and political privilege, invoking fears of metropolitan degeneration. In fictional stories of empire, tropical disease is similarly not simply a technology of realism, but a malleable placeholder for foreignness, itself an 'other' that threatens British protagonists. For Arata, imperial narratives at the fin de siècle are often underscored by the fantasy that primitive forces - which 'originate outside the civilised world', or can even 'inhere within the civilised itself'-might reverse the power relationship between the coloniser and colonised. ${ }^{66}$

Such primitive forces are often encoded by the aetiologies of tropical disease, which, in fiction, foresee a Britain epidemiologically compromised by its imperial practices. Whilst Arata highlights imperial romance-and what he calls 'imperial Gothic' - as genres that bespeak a pairing of

\footnotetext{
${ }^{64}$ Mark Harrison, "“The Tender Frame of Man”: Disease, Climate, and Racial Difference in India and the West Indies, 1760-1860' Bulletin of the History of Medicine, 70.1 (1996) 68-93 (p. 70).

${ }^{65}$ See: Caroline Levine, Forms: Whole, Rhythm, Hierarchy, Network (New Jersey: Princeton University Press, 2015).

${ }^{66}$ Stephen Arata, Fictions of Loss at the Victorian Fin de siècle: Identity and Empire (Cambridge: Cambridge University Press, 1996) p. 108.
} 
colonial fear and imperial guilt, Otis identifies the detective narrative as a mode that enacts a kind of 'imperial immune response' policing the borderlands of empire. ${ }^{67}$ As she argues, developments in neurology and cell biology provided a vocabulary in which to articulate nationhood as bounded by 'semi-permeable membranes', a notion that conceptualised the commercial possibilities and political pitfalls of global citizenship. ${ }^{68}$ Howell enriches this scholarship by identifying what she calls 'malarial Gothic', a mode that 'displac[es] visions of illness onto racial and national others'. ${ }^{69}$ In this book, I interrogate how the stories we tell ourselves about science and empire are mediated by such fictions, excavating how stylistic choices like these not only distil geopolitical anxieties about Britain's tropical possessions but also engage with and help to shape the shifting terrain of parasitic theories of disease transmission.

\section{MAPPING EMPIRE}

Finally, a word about empire. Several bodies of knowledge converged to form the clay out of which conceptions of empire were built. From human anthropology to climatology, from tropical medicine to evolutionary theory, from politics and commerce, to fiction set in colonial space, discussions of native peoples, flora, and fauna were in conversation with each other and with dominant ideologies of Britishness. Mary Louise Pratt, for example, identifies a kind of 'monarch-of-all-I-survey' discourse in the writings of British Nile explorers in the 1860s. Their travel writings become a form of 'verbal painting whose highest calling was to produce for the home audience the peak moments at which geographical "discoveries" were "won" for England'.$^{70}$ Such stories were mirrored by the Boy's Own Adventure genre, from which many young men would learn a form of jingoistic chivalric masculinity that would also come to underpin the rhetoric of tropical medicine. Together such writings were part of a process of what Pratt calls 'euro-imperial meaning-making', a practice that was particularly fraught during the period that this book examines.

\footnotetext{
${ }^{67}$ Laura Otis, 'The Empire Bites Back: Sherlock Holmes as an Imperial Immune System' Studies in 20th Century Literature 22.1 (1998) 31-60.

${ }^{68}$ Laura Otis, Membranes: Metaphors of Invasion in Nineteenth-Century Literature, Science and Politics (Baltimore: Johns Hopkins University Press, 1999).

${ }^{69}$ Jessica Howell, Malaria and Victorian Fictions of Empire, p. 9.

${ }^{70}$ Mary Louise Pratt, Imperial Eyes: Travel Writing and Transculturation (London: Routledge, 1992) p. 202.
} 
The years 1885-1935 encompass a period in which the moral, social, and political stakes of Empire were particularly visible amid anxiety about the continued viability of England's 'global prowess' and unease about the political, economic, institutional, and social relationships that supposedly facilitated it. The partition of Africa, the granting of self-rule to the 'settler' colonies, and increasing tensions following the Indian Rebellion (aka Indian Mutiny) (1857) and the Jamaica Rebellion (1865) form a backdrop to this book and in many respects galvanised the self-validating racism inherent in what Patrick Brantlinger has called the 'myth of the Dark Continent'. ${ }^{71}$ This myth was perpetuated by viewing Africa and Britain through a lens of dichotomies-darkness versus light, savagery versus civilisation, pathology versus salubrity. That is not to say, however, that imperialism was a unifying force or an ideology subscribed to universally. Rather, that the very destabilising of what Martin Green has called the 'energising myth of English imperialism' in this period-through global political competition, colonial concessions, and anti-imperial resistance movements-made the polarising rhetoric of colonial difference even more salient. $^{72}$

The scientific racism that underpinned this rhetoric was manifested in a form of medical cartography - a type of 'story-telling' that, for Tom Koch, represents 'neither the world nor an objective record of our worldly experience, but a means whereby we come to understand aspects of it'..$^{73}$ The mapping of the tropical world by the West in the nineteenth century encoded a paradox borne out, as David Arnold notes, of the simultaneous perception of the tropics as landscapes of natural abundance and fertility, and of disease and poverty: 'Europe's engagement with the tropics contained, almost from the outset, a duality that made the tropics appear as much pestilential as paradisiacal'. ${ }^{74}$ When I refer to the 'tropics' throughout this book, I follow James Duncan in recognising that

[t]he "tropics" was simultaneously a set of material facts (an area of the globe, characterised by certain climates, peoples and organisms), a set of

${ }^{71}$ Patrick Brantlinger, Rule of Darkness: British Literature and Imperialism, 1830-1914 (Ithaca: Cornell University Press, 1988) p. 174.

${ }^{72}$ Martin Green, Dreams of Adventure, Deeds of Empire (New York: Basic Books, 1979) p. 3.

${ }^{73}$ Tom Koch, Cartographies of Disease: Maps, Mapping, and Medicine (Redlands: ESRI Press, 2005) p. 6.

${ }^{74}$ Arnold, "“Illusory Riches"', p. 8. 
discourses (ideas and ways of thinking about this part of the globe and its relation to humans), and a set of projects (imperial, bureaucratic, commercial, religious and gendered ways of interacting, in part shaped by local structures, and in part by imperial structures that transcend the tropics). ${ }^{75}$

The tropics of fin de siècle parasitology were co-produced by diverse political, institutional, commercial, and social networks. Ross's mosquitomalaria work, for example, was precipitated by a desire for the investigation from members of the Indian Medical Service-supported by British specialists at home like Manson and spurred by a sense of international scientific competition-as well as by a desire from the Patiala government, the governor-general and sanitary commissioner of the Madras government, and the United Planter's Association of Southern India. ${ }^{76}$ The investigation and subsequent investigations into other parasitic diseases like sleeping sickness and kala-azar were also supported by institutions like the Liverpool and London schools of tropical medicine, and benefactors like Alfred Lewis Jones, Edwin Durning-Lawrence, and Lord Leverhulme. These professional networks were often inseparable from the personal relationships and politics that structured them; Leverhulme had a vested interest in tropical medical research owing to his commercial ventures with Sunlight Soap, which relied on palm oil obtained in Africa and Asia. Moreover, he was personal friends with Ross, supporting his application for a 'special' pension from the Under Secretary of State for India, swapping self-penned dramas, and hosting a reading of Ross's poetry at his home in Hampstead.

Ross chose to view his time in India through a poetic lens, detailed in his poetry collection Philosophies (1911). At the end of seven years stationed with the Indian Medical Service in Madras, Bangalore, Burma, and the Andaman Islands, Ross remarks that he 'began to be drawn toward certain thoughts which [...] had occurred to [him] in [his] profession'. These thoughts soon began to 'shape themselves into a kind of sonnet of three short stanzas' (iii). In the following poems, he draws on his professional and poetic authority to delimit India as an ancient fallen civilisation which, he fears, might foretell Britain's own imperial future: 'Here from

\footnotetext{
${ }^{75}$ James S. Duncan, 'The Struggle to be Temperate: Climate and "Moral Masculinity" in Mid-Nineteenth Century Ceylon' Singapore Journal of Tropical Geography 21.1 (2000) 34-47.

${ }^{76}$ See: London, LSHTM. RC. GB 0809 Ross/04/54/01 and 02. Letter correspondence, June 1897.
} 
my lonely watch-tower of the East/An ancient race outworn I see-/With dread, my own dear distant Country, lest/The same fate fall on thee' (1). Philosophies tells the story of his struggle to forestall that fate through tropical medicine, invoking a complementarity between science and sentiment that encapsulates the inherent tensions of this book. How can we write histories of medicine and empire that are sensitive to the cultural embeddedness of 'objective' knowledge and the narratives we use to communicate it?

It is important that we critically reflect on the intertwined histories of medicine and empire, especially now in the wake of a series of political and politicised episodes about nationalism, race, and so-called woke culture exemplified by recent backlash against postcolonial scholar Corinne Fowler's book Green Unpleasant Land (2020). The book, which examines 'four centuries of literary response to explore how race, class and gender have both created and deconstructed England's pastoral mythologies', prompted defensive retorts from the mainstream media misleadingly claiming that the book dubs 'gardening racist'. Such critiques are enmeshed within the wider contexts of the heritage 'culture wars', set against global Black Lives Matter protests and the dethronement of the statue of nineteenth-century slave trader, Edward Colston, in Bristol.

In the aftermath, many historians and academics of empire, like Fowler, have been accused of 'rewriting history'. Fowler co-edited a report by the National Trust investigating links between their properties and the slave trade which attracted criticism from conservative MPs who also disparaged Fowler's Colonial Countryside project, undertaken in collaboration with the National Trust and British primary schools. Former Cabinet minister Lord Peter Lilley demonstrated the emotional resonance of the debate and the deep ideological ties between place and identity when he insisted that Fowler 'has insulted her country by her book whose very title-Green Unpleasant Land-tells us what she thinks of her fellow citizens' ${ }^{77}$

Lilley suggests that criticism of England's colonial past is unpatriotic. Certainly, evidence that 'the slavery business [...] shaped philanthropy and philanthropic giving in this country' is uncomfortable. ${ }^{78}$ But we must

\footnotetext{
${ }^{77}$ Mark Edmonds, 'Academic says GARDENING has its roots in racial injustice' Daily Online, 16 January 2021 https://www.dailymail.co.uk/news/article-9153499/Academicsays-GARDENING-roots-racial-injustice.html.

${ }^{78}$ Hardeep Matharu, 'Anti-Woke Crusade Igniting Threats to Safety \& Careers' Byline Times, 11 February 2021 https://bylinetimes.com/2021/02/11/anti-woke-crusadeigniting-threats-to-safety-and-careers-theres-so-much-hatred-projected-at-women-in-
} 
face this discomfort because, as Sathnam Sanghera illustrates in Empireland (2021), imperialism has shaped modern Britain. From our language to our architecture, and from curry to cups of tea, the legacies of our colonial past, for good and for ill, are irrevocably part of the fabric of Britain in $2021 .{ }^{79}$ Science is no exception, and neither are the stories we tell about it. As an interdisciplinary study of the history of British parasitology, Empire Under the Microscope deepens our understanding of the cultural investments of scientific practice and reveals the multiform entanglements between science, empire, and the literary imagination at the turn of the century.

public-life-warns-historian/?fbclid=IwAR3hkyyhPKxnKP2aqa6f0EeI2VVWw4DFSQmA81 wb9RAubsuMVnzVLsefKuw.

${ }^{79}$ See: Sathnam Sanghera, Empireland: How Imperialism Has Shaped Modern Britain (London: Viking Books, 2021).

Open Access This chapter is licensed under the terms of the Creative Commons Attribution 4.0 International License (http://creativecommons.org/licenses/ by $/ 4.0 /$ ), which permits use, sharing, adaptation, distribution and reproduction in any medium or format, as long as you give appropriate credit to the original author(s) and the source, provide a link to the Creative Commons licence and indicate if changes were made.

The images or other third party material in this chapter are included in the chapter's Creative Commons licence, unless indicated otherwise in a credit line to the material. If material is not included in the chapter's Creative Commons licence and your intended use is not permitted by statutory regulation or exceeds the permitted use, you will need to obtain permission directly from the copyright holder.

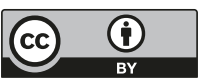

